\title{
INTEGRATING INFORMATION AND COMMUNICATION TECHNOLOGIES IN THE PROCESS OF FOREIGN LANGUAGE TEACHING AND LEARNING
}

\author{
NATALIA SEROSTANOVA \\ Chair of Foreign Languages, \\ Voronezh Institute of the Ministry of Interior of Russia \\ Prospect Patriotov 53, 394065, Voronezh, Russia \\ Email address: serostanova-nata@mail.ru
}

(C) $\mathcal{( 0 ) \Theta}$

\begin{abstract}
The paper is an attempt to cover some of the issues of using information and communication technologies (ICT) in foreign languages teaching and learning (FLT/FLL) on the basis of intercultural approach. The facilities of Internet along with computer programs, audio and video devices, interactive whiteboards and telecommunications are considered. Special attention is given to the peculiarities of telecommunication projects; the example of telecommunication project realization is represented. The advantages and disadvantages of distance language learning are considered. Besides, some difficulties that students and teachers come across during ICT-supported language education are also discussed.
\end{abstract}

Key words: information and communication technologies (ICT), foreign language teaching and learning (FLT/FLL), computer programs, interactive whiteboards, Internet-based (telecommunication) projects, distance learning

\section{INTRODUCTION}

Alongside with the global processes of informatization of the society, communication and information technologies (ICT) have also penetrated the sphere of education. The use of ICT is widespread in the contemporary process of foreign language teaching and learning (FLT/FLL). The new technologies are breaking down borders and barriers at a faster rate than is possible in physical terms. Suddenly, unexpected encounters with other languages and cultures confront people throughout the world with new choices, opportunities and challenges (Fitzpatrick, 2004).

One of the most important developments in foreign language education over the past two decades has been the realization of the importance of culture in FLT/FLL. ICT have undoubtedly facilitated the integration of authentic intercultural communicative activities into the classroom. They have offered new possibilities of access to plenty of current, up-to-date materials from the country or countries of the target language and even to contact actual speakers of other languages in distant locations. 
Though ICT present a powerful learning environment for both learners and teachers (Smeets, 2005), there is much dispute on their positive and negative effects on the process of foreign language acquisition. Thus, in this paper we provide an overview of the pros and cons of ICT implementation, particularly numerous devices, and consider the peculiarities of distance language learning as well as Internet-based projects realization.

So, the main aims of the research are as follows:

1) critical review of the modern ICT, advantages and disadvantages of their application in FLT/FLL;

2) analyzing the teacher role in the ICT - based educational process;

3) proving efficiency of ICT using in practice, realization of telecommunication project being as an example.

\section{THEORETICAL ISSUES}

With the advent of computer different terms have been used which imply its overall usage in the sphere of language education: CALI (Computer-Assisted Language Instruction, 1960s-1970s) based on a teacher-centered approach (instructional); CALL (Computer Assisted Language Learning, 1980) focused mainly on a student-centered approach; TELL (Technology-Enhanced Language Learning, 1990) which refers to the use of the computer as a technological innovation.

Nowadays the term blended learning has become extremely fashionable, but it is not new. It is a combination of face-to-face and computer assisted learning (CAL) in a single teaching and learning environment (Neumeier, 2005); any combination of face-to-face teaching with computer technology (online and offline activities/ materials) (Tomlinson, Whittaker, 2013). Many experts in the field prefer to talk about Information and Communication Technologies (ICT) rather than CALL, focusing mainly on communication technologies which include Internet, wireless networks, cell phones, and other communication media.

ICT are concerned with the storage, retrieval, manipulation, transmission or receptionof digital data. The data is transferred or communicated to people over long distances by electronic means. In the past few decades ICT have created "global information space" providing people with possibilities of "lifelong learning" and improving language skills as well.

\section{AUDIO-VISUAL DEVICES}

However, such audio-visual devices as CD / DVD player, audiocassette recorder, video camera and computer programs continue to be the most widely used by modern language teachers. Their application is justified psychologically, as these are the auditory and visual organs that let a person get the main information about the surrounding world. Besides, such information is more available for perception and better and faster learning.

Computer programs designed for FLT/FLL can fall into four categories: 1) training programs (game programs, training simulators); 2) monitoring programs 
(testing shell); 3) information retrieval, information and reference programs (electronic dictionaries and glossaries); 4) computer-assisted programs (Golubeva, Repina, 2004).

There exist some other classifications of computer programs, but what we want to focus on is emphasize their advantages over traditional teaching techniques. Their main distinctive features are multimedia format (combination of different ways of information representation) and interactivity ("dialogue" relations between a computer and a learner). They provide large data capacity; it allows representing any linguistic model in different contexts and speech situations. In addition, computer programs stimulate students' self-directed learning, cognitive activity and intensify their learning motivation. Learners can choose their own pace and exercises depending on their level of language proficiency, it promotes stress relief and creates favorable psychological climate.

Some programs (templates) possess features of adding supplementary exercises, thus enabling teachers to create their software. Teachers can choose an authoring program that best fits their technical skills and design materials according to their teaching styles and students' needs (Jurich, 2001).

\section{INTERNET}

With the introduction of the Internet, teachers and learners have at their disposal an instrument which combines all the advantages of audio-visual aids. Being the key source of all kinds of information, the Internet has become an additional means of getting authentic audio and video materials.

Integrating information resources of the Internet in a language classroom allows completing different didactic FLT/FLL tasks:

- to form reading abilities and skills using materials of different degree of complexity;

- to develop and improve listening skills on the basis of authentic audio texts from the Internet;

- to improve skills of monolog and dialogue speech in the process of problem discussion of Internet information;

- to improve writing skills using e-mail, chat, etc.

- to enlarge active and passive vocabulary with contemporary language units;

- to get to know cultural features including customs, traditions, speech etiquette of the country of the target language;

- to form motivation to FLL.

The Internet also offers a wide variety of reference materials like online dictionaries, e-encyclopedias and search mechanisms very helpful for developing students` individual learning trajectory.

\section{INTERACTIVE WHITEBOARD}

Interactive whiteboards have become popular over the last few years and they seem to have a greater array of educational tools due to software development. 
Designing learning process around interactive whiteboards helps teachers ease their preparation, be more efficient in their ICT integration and increase their productivity in general.

Interactive whiteboard is a modern multimedia device. It is like a regular white board, but provides possibilities of commenting on-screen images which can then be printed or saved like any other document. It affects learning in several ways, including raising the level of student engagement in the classroom, motivating students and promoting enthusiasm for learning (Bacon, 2011). Interactive white boards support many different learning styles and are used in a variety of learning environments (Chapell, 2003). Immediate Internet access while working with the interactive white board makes it a unique tool to interact with digital culture, language content and multimedia. Foreign language learning activities may include:

- active commenting on the teaching material: highlighting, correction, addition of supplementary information with a special marker;

- work with the text, translation of some sentences pointing out connections and relations between different words;

- typing on virtual keyboard and its viewing on-line;

- using numerous pictures helping to understand unknown words and make the lesson more interesting;

- web-cites, video watching by the whole class;

- conference communication

- moving objects on the board, their grouping according to some principle;

- saving notes for later review;

- manipulating texts, tables and images;

- using presentation tools to enhance learning materials.

Nevertheless, teachers can have some difficulties when implementing interactive white boards in the process of FLT:

- labour-intensive process of lessons preparation using the boards;

- software and interactive whiteboards incompatibility which can sometimes occur;

- high costs of hardware and software;

- sufficient level of using ICT, which is a necessity for a modern teacher.

The research shows that interactive learning promotes relaxation, attention switch, changing different types of language activities. As a result, it saves time, stimulates mental and creative development, making all the students active and motivated during a lesson, which leads to effective FLT/FLL.

\section{TELECOMMUNICATION PROJECTS}

Project work has proved out to be an effective teaching method, as it allows combining theoretical knowledge with its practical use for solving specific problems working together. But ICT immensely widen the boarders of project activities. Students can participate in Internet-based (telecommunication) projects, communicate on-line with other students abroad, discuss problems, and learn the ins and outs of foreign culture and way of life. 
Telecommunication project is collaborative, research, creative students' activity on the basis of computer telecommunication; it has the collective goal, problems, coordinated methods and ways of solving problems and aims at achieving the end result (Polat, 2000).

There are different points of view on the stages of telecommunication project. We can separate out the following three stages: 1) preparation stage; 2) procedural stage and 3) final stage. At first students get recommendations from their instructor (teacher), and then they get acquainted with the evaluation scale. After that, the students together with their instructor choose the project themes, work out the plan, including the goals. Then, students are divided into groups and define their roles. They collect all the information concerning the project and analyze it in groups. They can also chat with e-mail friends, if the project is international. Then they decide how to achieve the results, choose the type of presentation. It can be a web-page, a report, a Power Point Presentation and so on. When they are ready, they present their projects. Then students evaluate other groups' projects and their own ones. Together with their instructor they discuss the results and analyze the difficulties.

Though similar in many ways, telecommunication projects can take on diverse forms. The most suitable format for a given context depends on a variety of factors, including curriculum objectives, course expectations, learners' proficiency levels, interests, time constraints, and availability of the materials.

There are some important features of telecommunication project in the process of FLT/FLL. They are the following:

- problem-orientation; the project is carried out in the process of putting and solving problem situations, culture or professionally oriented; which suggests the reference to professional and personal students experience, their professional plans, interests and needs;

- self-dependence; it is one of the main characteristics of the modern education as well, which allows learners to get the skills of self-learning; the project stimulates self-dependence in finding information, making decisions, facilitates the students mental set for systematic supplement of knowledge and development of skills to orientate in the information flow;

- collaboration; The important trait of telecommunication projects is constructive collaboration of students and their instructor. At first the instructor has a leading role coordinating the project, then he/she only helps students in solving problems, supervises them and collaborates giving them possibilities for self-independence and self-realization.

- inter-disciplinary character; project realization needs the use of knowledge from other subjects;

- creativity; project work provokes its participants' creativity, which results in final product;

- dynamism and novelty; which are provided through the novelty of project themes, different forms of work (individual, in groups and in teams), various project stages and types of tasks.

The analysis of psychological and pedagogical literature allowed us to sort out the didactic functions of telecommunication projects significant from the educational point of view: 
1) organizational, TP gives the opportunity to organize research and creative activity of students and teachers from different universities of the region and different countries;

2) informational, it includes the search and exchange of information, plans and ideas on various themes, expanding students outlook and raising the level of their knowledge;

3) interactive, that aims at interactive students and teachers collaboration, which is shown in friendly atmosphere and mutual support leading to the understanding, joint resolution of project goals;

4) motivational; TP creates the conditions for the students to reveal their abilities, show their individuality, raising the interest and motivation for acquiring foreign language while preparing presentation of the final project product;

5) integrative; the realization of this function includes forming of the whole system of students linguistic knowledge and individual qualities in their unity during project realization

So, we would like to point out some special features of TP in the process of FLT/FLL. They are the following:

- Telecommunication project is student-centered, though the teacher plays a major role in offering support and guidance throughout the process.

- Telecommunication project usually focuses on cultural or professional content learning. Real-world subject matter and topics of interest to students can become central to projects.

- Telecommunication project is cooperative rather than competitive.

- Telecommunication project culminates in an end product that can be shared with others, giving the project a real purpose. The value of the project, however, lies not just in the final product but in the process of working towards the end point. Thus, project work has both a process and product orientation, and provides students with opportunities to focus on fluency and accuracy at different project - work stages.

- Telecommunication project is potentially motivating, stimulating, empowering, and challenging.

Thus, while working on the project, such students' qualities, necessary for their future career, as responsibility, initiative, communication, creativity, mobility, ability to work in a team, readiness to collaborate, self-organization and self-education are developed. Project work also results in improving students' language skills, content learning, and cognitive abilities.

\section{DISTANCE LEARNING}

The continuous growth of ICT makes distance learning in the form of e-learning (Electronic Learning) very popular in the process of FLT/ FLL. It includes using multimedia devices, browsing educational resources on the Internet, synchronous (video and audio conferences, chats) and asynchronous (e-mails, forums, message boards) communication via Internet, creating own resources (web pages) and distance learning resources development. 
There are three groups of computer programs which are oriented towards distance FLL/FLL:

1) programs devoted to learning different parts of the language system (introduction and activization of linguistic forms and patterns);

2) programs allowing organizing different forms of speech activity;

3) controlling programs which aim at assessment of language skills forming.

Though it's difficult to imitate real speech practice with the help of computer programs, they provide teaching material introduction, modeling of communication situations, playing exercises, control and assessment of knowledge. Multimedia means can provide enhanced level of interactivity by combining multiple media content.

There are some other distance technologies that are applied in FLT/ FLL. Case - technology is close to the extra-mural education. Students get a set of teaching and learning aids (case) on paper or CD for self-learning and consult teachers from time to time. TV-technology relies on TV lectures and using consultations. Network technology is based on using the Internet for providing students with consultations and educational aids (Vishnevskaya, 2011).

In spite of the obvious advantages of distance learning (availability, flexibility of learning schedule, interactive character, individualized education, chance to communicate with native speakers, favorable conditions for creative activity, etc.), there exist some technical and psychological problems.

Technical difficulties can be connected with technical imperfections and expensive hardware and software. Teachers and learners have to be computer-literate enough to succeed in such type of learning.

As for psychological problems, their main reason is the absence of face-to-face communication. Some students find it difficult to communicate via the Internet. Another problem is self-discipline and self-organization. Only high-motivated learners can achieve success in distance learning.

So, integrating distance learning in the process of FLT/FLL should be realized step-by-step according to learners' needs and abilities.

\section{THE ROLE OF THE TEACHER}

The introduction of ICT calls for new learning and teaching patterns (Fitzpatrick, 2004). Language teachers are required to take on new roles. They are not authoritarian and not the only source of knowledge any longer. Being responsible for creating successful language learning environment, they need to be knowledgeable and aware of all the possibilities ICT can bring into the language classroom. They should also be computer-literate, i.e. be able to use standard software competently. They need to recognize the individual learning problems of learners and make a thoughtful choice concerning the use of ICT.

Teachers should be placed in the role of facilitators and guides in the learning process. Their task is to help, direct, explain, and give moral support. Nevertheless, it is very important that communication between the teacher and the student, and among students themselves, is not lost. That is why adequate ICT using according to the aims and needs of language teaching and learning should take place. 


\section{PRACTICAL EXPERIENCE}

All the ICT mentioned above are widely used in the process of FLT/FLL in Voronezh institutes of higher education, proving their efficiency in training specialists. In this paper we want to describe the experience of organization and realization of Internet-based project “How to organize my own business?" (2011).

This project was based on such methods as: PBL (Problem Based Learning) implying students' gaining new knowledge through the experience of problem solving, professionally-oriented one in our case; collaborative learning meaning learners' engagement in common task and active interaction with each other via face-to-face conversations and computer discussions to achieve the common aim; method of information resources assuming students' ability to find the necessary information in its abundant resources, as well as enough level of computer literacy to manage the information.

It was an interdisciplinary project, as it was carried out while teaching the English language and Economics. Students of Economics Faculties from five institutes of higher education (Voronezh State Technical University, Voronezh Institute of High Technologies, Russian New University (Voronezh Subsidiary), Voronezh State Agricultural University and Voronezh State University of Engineering Technologies) took part in the project. The participants created business plans of various enterprises ("Confectionary", "Florist", "Photo-studio", "Shoe repair shop", "Travel Internet shop", "Hairdresser's", etc.), uploaded them to the site (www.howbusiness.ukoz.ru), evaluated the projects of other participants and took an on-line test.

This Internet-based project lasted for two months. It can be characterized as a research, professionally and culture-oriented and creative one. Its main stages are presented below.

Tab. 1. The main stages of the Internet-based project "How to organize my own business?"

\begin{tabular}{|c|c|c|c|}
\hline STAGES & PROJECT SCORE & $\begin{array}{l}\text { LEARNER'S } \\
\text { ACTIVITY }\end{array}$ & $\begin{array}{l}\text { TEACHER'S } \\
\text { ACTIVITY }\end{array}$ \\
\hline - Registration & \multicolumn{3}{|c|}{$\begin{array}{l}\text { Registration on the cite www. howbusiness.ucoz.ru, } \\
\text { site admin confirmation }\end{array}$} \\
\hline $\begin{array}{l}\text { 1. DESIGNING } \\
\text { STAGE }\end{array}$ & $\begin{array}{l}\text { 1.dividing into } \\
\text { groups ( } 3-4 \text { stu- } \\
\text { dents); } \\
\text { 2. choosing the field } \\
\text { of the future firm; } \\
\text { 3. studying the } \\
\text { examples of busi- } \\
\text { ness plans, the main } \\
\text { requirements for } \\
\text { their creation; } \\
\text { 4. allocation of re- } \\
\text { sponsibilities inside } \\
\text { the group }\end{array}$ & $\begin{array}{l}\text { discussing the } \\
\text { problem, aims and } \\
\text { results; making-up a } \\
\text { plan and setting the } \\
\text { main stages of the } \\
\text { project. }\end{array}$ & $\begin{array}{l}\text { working out me- } \\
\text { thodical project } \\
\text { map, directing } \\
\text { learners at the fi- } \\
\text { nal results, giving } \\
\text { advice and help if } \\
\text { needed, monitoring } \\
\text { learners activity, } \\
\text { supervision }\end{array}$ \\
\hline
\end{tabular}




\begin{tabular}{|l|l|l|l|}
\hline$\underline{\text { 2. ACTIVITY }}$ & $\begin{array}{l}\text { 1. preparing busi- } \\
\text { ness-plans, search- } \\
\text { ing for necessary } \\
\text { information on the } \\
\text { Internet; } \\
\text { 2. analyzing the } \\
\text { specifics of business } \\
\text { plans creation in } \\
\text { other countries; } \\
\text { 3. discussion of } \\
\text { preliminary project } \\
\text { design }\end{array}$ & $\begin{array}{l}\text { finding all the in- } \\
\text { formation using } \\
\text { Internet, discussing } \\
\text { it and preparing the } \\
\text { project }\end{array}$ & $\begin{array}{l}\text { giving assistance } \\
\text { and advice, cooper- } \\
\text { ating with learners, } \\
\text { participating in } \\
\text { discussing the inter- } \\
\text { mediate results }\end{array}$ \\
\hline $\begin{array}{l}\text { 3. EVALUAT- } \\
\text { ING STAGE }\end{array}$ & $\begin{array}{l}\text { 1.presentation of } \\
\text { business plans, up- } \\
\text { loading them to the } \\
\text { site; } \\
\text { 2. evaluating and } \\
\text { commenting of } \\
\text { business plans } \\
\text { presented by other } \\
\text { participants }\end{array}$ & $\begin{array}{l}\text { projects presenta- } \\
\text { tion, evaluating } \\
\text { other projects and } \\
\text { own one. }\end{array}$ & $\begin{array}{l}\text { monitoring learn- } \\
\text { ers activity, asking } \\
\text { questions as a par- } \\
\text { ticipant, } \\
\text { evaluating the proj- } \\
\text { ect results }\end{array}$ \\
\hline $\begin{array}{l}\text { - Summing up } \\
\text { the results of } \\
\text { the project }\end{array}$ & $\begin{array}{l}\text { Experts (teachers of English and Economics) analyze the business } \\
\text { plans and choose the best ones, whose authors are the winners. }\end{array}$ \\
Source: Own research & \\
\hline
\end{tabular}

The results of the project were evaluated by a group of experts including teachers of English, Economics and Information Technologies in the terms of the originality, innovation, economic profitability, the quality of presentation of the business-plans as well as their readiness correspondence to the timetable. As concerns the linguistic aspect, consistency, organization, correct and wide usage of economic terms, reasonableness of the content were considered. So the best business-plans were chosen and the winners were announced.

The analysis of the test for the project participants showed that $75 \%$ of the learners were satisfied with the project and considered such experience to be useful for their future profession. $56 \%$ of the students noticed the project facilitated developing their initiative, ability of team work, self activity, creativity, self-criticism and responsibility. $35 \%$ of the participants prefer team work. In turn, teachers emphasized increasing motivation to FLL, collaboration and communication skills development.

It should be noted that the project realization contributed to the development of such students skills as research (skills to analyze problems, hypothesize, compare, summarize and conclude); information (skills to find, sort out, evaluate and use all kinds of information and ICT in a proper way); communicative (skills to work in a team, communicate via Internet) and creative (skills to generate new ideas, invent something new, find different solutions to the problem).

To sum up, the interdisciplinary Internet-based project turned out to prove worthy using of ICT in FLT/FLL and specialty (economic) subjects teaching. 


\section{CONCLUSION}

The research indicates that among the main advantages of using ICT in the process of foreign language acquisition the following ones can be named:

- authentic context, that reflects the way the language will be used in real life, thus providing the purpose and motivation for learning;

- cultural understanding, the possibility to get acquainted with the way of life of the target language community, to visit distant places without leaving home, which makes learning the language part of a cultural experience;

- great amount of tools for teachers and learners (audio and video devices, television and radio broadcasts, synchronous (video and audio conferences, chatting) and asynchronous (e-mail, forum, web logs, message boards) Internet-based communication, which facilitates improving reading, listening, speaking skills and grammar knowledge;

- involvement in collaboration and cooperation, participating in Web-projects and working in a physically-separated team promotes learners' creatively thinking, encourages to solve problems and to make decisions as a team;

- removing the time and space limitations, which allows students to learn more autonomously at different rates and levels, without interruptions, time pressure and social anxiety, and thereby raises self-esteem and confidence;

- immediate feedback and error analysis, which can be provided by the computer and teachers as well, and help the learners ward off their misconception at the very first stage.

While ICT have been widely implemented in the process of foreign language teaching and learning, teachers and learners come across some problems. The disadvantages of ICT using are as follows:

- lack of familiarity with technologies, primarily teachers' lack of an adequate understanding of the technologies' potential and limitations, and consequently a lack of adequate learning process planning; both students and teachers' low level of computer literacy;

- lack of students motivation, lack of "face-to-face" communication with teachers and the problems of self-discipline and self-organization that depend on motivation;

- financial barriers, including the cost of setting up a network and suitable software which can be rather expensive.

For the successful integration of ICT in the process of foreign language teaching and learning, both teachers and learners need to be prepared to adopt new roles and use the available technology in appropriate ways. Teachers should be equipped with professional skills which include pedagogical and technical know-how, because the more enthusiastic and more knowledgeable the language teachers are, the more successfully they can implement ICT in the language classroom. Teachers should also be aware of changing their role from an instructor to a facilitator and a guide. Learners can only benefit from technology-based activities provided that these activities are relevant to their needs and interest. 
So, modern ICT possess a great educational potential in FLT/FLL. On the one hand, they are used for language and communication skills development; on the other hand, they can act as a stimulus which generates analysis, critical and creative thinking, and motivation. Therefore, it is absolutely necessary to realize all the limitations and weakness ICT still have, and carefully plan the educational process at all the stages of introduction and implementation of new ICT according to the specific needs of teachers and learners.

As for the practical experience, the organized telecommunication project proved the effectiveness of ICT implementation which does not only provide improving language, communicative, information, research and creative skills but also develops important learners' personality qualities.

\section{REFERENCES}

Bacon, D. (2011). The interactive whiteboard as a force for pedagogic change. Information Technology in Education Journal, 15-18.

Chapelle, J. (2003). How Is the Interactive Whiteboard Being used in Primary School. Becta Research Bursary. Retrieved February 15, 2014, from http: / / www.virtuallearning.org.uk/whiteboards/ IFS_interactive whiteboards_in_the primary_school.pdf.

Fitzpatrick, A. (2004). Information and Communication Technologies in the Teaching and Learning of Foreign Languages: State-of-the-Art, Needs and Perspectives. Analytical Survey, UNESCO Institute for Information Technologies in Education, Moscow. Retrieved February 12, 2014, from http:/ /iite.unesco. org/pics/publications/en/files/3214627.pdf.

Golubeva, T., Repina, S. [Голубева, Т., Репина, C.] (2004). Применение информационных технологий в обучении иностранному языку [Information Technologies Application in Foreign Language Teaching], Orenburg: Orenburg State University.

Jurich, S. (2001). ICT and teaching of foreign languages. Retrieved February 12, 2014, from http://www. techknowlogia.org/TKL_Articles/PDF/335.pdf.

Neumeier, P (2005). A closer look at blended learning - parameters for designing a blended learning environment for language teaching and learning. ReCALL, 17/2, 163-178.

Polat, Е. [Полат Е.С.] (2000). Метод проектов на уроках иностранного языка. [Project Method at Foreign Language Lesson]. Иностранные языки в школе, 3,3-10.

Smeets, E. (2005). Does ICT contribute to powerful learning environments in primary education? Computers $\mathcal{E}$ Education, 44, 343-355. Retrieved January 28, 2014, from http://users.ntua.gr/vvesk/ ictedu/article4_smeets.pdf

Tomlinson, B., Whittaker C. (2013). Blended Learning in English Language Teaching: Course Design and Implementation. London: British Council.

Vishnevskaya, G. [Вишневская Г.] (2011). Внедрение дистаниионных технологий в процесс обучения иностранному языку студентов-заочников неязыковых вузов [Introduction of Distance Technologies in the Process of Foreign Language Teaching External Students of Non-linguistic Institutes of Higher Education]. Известия ПГПУ им. В. Г. Белинского, 24, 589-592.

Warschauer M., (1997). Computer-Mediated Collaborative Learning: Theory and Practice. The Modern Language Journal, 81(4), 470-481. Retrieved February12, 2014, from http: http:/ /www.gse.uci.edu/ person/warschauer_m/docs/cmcl.pdf.

White C. (2003). Language Learning in Distance Education. Retrieved February 15, 2014, from http:// bilder.buecher.de/zusatz/23/23832/23832755_lese_1.pdf 